\title{
Mode of Action of 1-Naphthylphthalamic Acid in Conspicuous Local Stem Swelling of Succulent Plant, Bryophyllum calycinum: Relevance to the Aspects of Its Histological Observation and Comprehensive Analyses of Plant Hormones
}

\author{
Agnieszka Marasek-Ciolakowska ${ }^{1, *++^{\mathbb{D}}}$, Michał Dziurka ${ }^{2,+} \mathbb{D}$, Urszula Kowalska ${ }^{1} \mathbb{D}$, Justyna Góraj-Koniarska ${ }^{1} \mathbb{D}$, \\ Marian Saniewski ${ }^{1}$, Junichi Ueda ${ }^{3}$ and Kensuke Miyamoto ${ }^{4, *}$ \\ 1 The National Institute of Horticultural Research, Konstytucji 3 Maja 1/3, 96-100 Skierniewice, Poland; \\ urszula.kowalska@inhort.pl (U.K.); justyna.goraj@inhort.pl (J.G.-K.); marian.saniewski@inhort.pl (M.S.) \\ 2 The Franciszek Górski Institute of Plant Physiology, Polish Academy of Sciences, Niezapominajek 21, \\ 30-239 Kraków, Poland; m.dziurka@ifr-pan.krakow.pl \\ 3 Department of Biological Science, Graduate School of Science, Osaka Prefecture University, 1-1 Gakuen-cho, \\ Naka-ku, Sakai, Osaka 599-8531, Japan; ueda@b.s.osakafu-u.ac.jp \\ 4 Faculty of Liberal Arts and Sciences, Osaka Prefecture University, 1-1 Gakuen-cho, Naka-ku, Sakai, \\ Osaka 599-8531, Japan \\ check for \\ updates \\ Citation: Marasek-Ciolakowska, A.; \\ Dziurka, M.; Kowalska, U.; \\ * Correspondence: agnieszkamarasek@wp.pl (A.M.-C.); miyamoto@las.osakafu-u.ac.jp (K.M.); \\ Tel.: +48-46-8346783 (A.M.-C.); +81-72-254-9741 (K.M.) \\ + These authors contributed equally to this work.
}

Góraj-Koniarska, J.; Saniewski, M.; Ueda, J.; Miyamoto, K. Mode of Action of 1-Naphthylphthalamic Acid in Conspicuous Local Stem Swelling of Succulent Plant, Bryophyllum calycinum: Relevance to the Aspects of Its Histological Observation and Comprehensive Analyses of Plant Hormones. Int. J. Mol. Sci. 2021, 22, 3118. https://doi.org/10.3390/ ijms22063118

Academic Editor: Stephan Pollmann

Received: 22 February 2021

Accepted: 15 March 2021

Published: 18 March 2021

Publisher's Note: MDPI stays neutral with regard to jurisdictional claims in published maps and institutional affiliations.

Copyright: (c) 2021 by the authors Licensee MDPI, Basel, Switzerland. This article is an open access article distributed under the terms and conditions of the Creative Commons Attribution (CC BY) license (https:/ / creativecommons.org/licenses/by/ $4.0 /)$.

Abstract: The mode of action of 1-naphthylphthalamic acid (NPA) to induce conspicuous local stem swelling in the area of its application to the growing internode in intact Bryophyllum calycinum was studied based on the aspects of histological observation and comprehensive analyses of plant hormones. Histological analyses revealed that NPA induced an increase in cell size and numerous cell divisions in the cortex and pith, respectively, compared to untreated stem. In the area of NPA application, vascular tissues had significantly wider cambial zones consisting of 5-6 cell layers, whereas phloem and xylem seemed not to be affected. This indicates that stem swelling in the area of NPA application is caused by stimulation of cell division and cell enlargement mainly in the cambial zone, cortex, and pith. Comprehensive analyses of plant hormones revealed that NPA substantially increased endogenous levels of indole-3-acetic acid (IAA) in the swelling area. NPA also increased endogenous levels of cytokinins, jasmonic acid, and its precursor, 12-oxo-phytodienoic acid, but did not increase abscisic acid and gibberellin levels. It was shown, using radiolabeled ${ }^{14} \mathrm{C}-\mathrm{IAA}$, that NPA applied to the middle of internode segments had little effect on polar auxin transport, while 2,3,5-triiodobenzoic acid substantially inhibited it. These results strongly suggest that NPA induces changes in endogenous levels of plant hormones, such as IAA, cytokinins, and jasmonic acid, and their hormonal crosstalk results in a conspicuous local stem swelling. The possible different mode of action of NPA from other polar auxin transport inhibitors in succulent plants is extensively discussed.

Keywords: crassulaceae; cytokinin; hormonal crosstalk; indoleacetic acid; jasmonic acid; polar auxin transport; stem swelling; succulent plant

\section{Introduction}

Plant growth, such as cell elongation, cell division, and cell enlargement, is primarily regulated by plant hormones and other plant growth substances. Among plant hormones, naturally occurring auxin, indole-3-acetic acid (IAA), mainly synthesized in the apical part of shoots and young leaves, shows a specific basipetal movement known as polar auxin transport. In this process, auxin is transported basipetally between cells toward the root tip through the stele in the aboveground parts, and then redirected symmetrically 
in specific root tip cells, and transported back towards the root elongation zone [1-7]. Commonly used polar auxin transport inhibitors such as 1-naphthylphthalamic acid (NPA), 2,3,5-triiodobenzoic acid (TIBA) and morphactins (methyl 2-chloro-9-hydroxyfluorene9-carboxylic acid, IT 3456, and 9-hydroxyfluorene-9-carboxylic acid, HFCA) have been demonstrated to show various effects by interfering with polar auxin transport and changing auxin distribution, and in consequence, to perturb auxin-related plant growth and development like root formation, cell elongation, and tropisms (see review by Ueda et al. [6]).

Recently, NPA was found to exhibit unexpected physiological effects in succulent plants: NPA did not inhibit root formation in shoot cuttings of Bryophyllum calycinum, $B$. daigremontianum, Kalanchoe tubiflora, and K. blossfeldiana, while TIBA and morphactins (IT 3456 and HFCA) completely inhibited it in these species [7]. NPA also did not inhibit root development on plantlets formed on leaves excised from intact $B$. marnierianum, acting in the opposite way to TIBA [8]. In addition, unlike TIBA and HFCA, NPA did not affect the induction of epinasty and petiole bending induced by exogenously applied IAA in intact and detached B. calycinum leaves $[9,10]$. We also found that NPA induced conspicuous local stem swelling only in the area of its application in intact plants of B. calycinum, and in the decapitated ones when IAA was applied simultaneously on the top of the internode [11].

In contrast, the application of TIBA [11] and HFCA (Saniewski et al. [11], unpublished results) in the same manner to B. calycinum plants did not induce conspicuous local stem swelling, whereas slight swelling along the entire internode above the treatment area was observed. These results suggest that the mode of actions of NPA is different from that of TIBA and HFCA in species of the family Crassulaceae, and that stem swelling in $B$. calycinum is caused by the interaction with NPA and IAA.

However, the mechanism by which NPA induces conspicuous local stem swelling has remained unclear. The purpose of this study was to clarify the mechanism of NPA stimulating effect on local stem swelling in B. calycinum based on the aspects of its histological observations and comprehensive analyses of plant hormones. The relationships between NPA and polar auxin transport in stem swelling and rooting of shoot cuttings in succulent plants are also discussed.

\section{Results}

\subsection{Effect of NPA on Conspicuous Local Stem Swelling in Succulent Plants}

As described in the Introduction, we have reported that NPA induced conspicuous local stem swelling only at the site of its application in intact plants and in the decapitated internode of B. calycinum when IAA was applied simultaneously on the top of the internode [11]. It should be mentioned that such conspicuous local stem swelling was not induced by the application of TIBA [11] or HFCA (Saniewski et al. [11], unpublished results). As shown in Figure 1, conspicuous local stem swelling induced by NPA was confirmed in the present study. NPA substantially induced conspicuous local stem swelling also in some other succulent plants, such as B. daigremontianum, K. tubiflora, and Sedum spectabile (Figure 1), but TIBA did not show that effect (see Saniewski et al. [11]). This fact suggests that, differently from TIBA, NPA induces conspicuous local stem swelling as an unusual mode of action regarding some auxin-regulated process in succulent plants.

In our previous study, rooting of B. calycinum, B. daigremontianum, K. tubiflora, and K. blosfeldiana shoot cuttings was inhibited by the application of TIBA and morphactin (IT 3456), however, not by NPA [7]. As shown in Figure S1 and Table S1, shoot cuttings of $S$. spectabile easily rooted and developed a root system well, when they were incubated both in water and soil medium. The application of TIBA $(0.2 \%, w / w)$ or $\operatorname{HFCA}(0.2 \%, w / w)$ almost completely inhibited root formation and shoot growth. In contrast, NPA $(0.4 \%, w / w)$ application neither inhibited root formation nor shoot growth in the cuttings, regardless of growth conditions. These results strongly support the hypothesis that NPA shows unusual effects unlike other polar auxin transport inhibitors in succulent plants. 


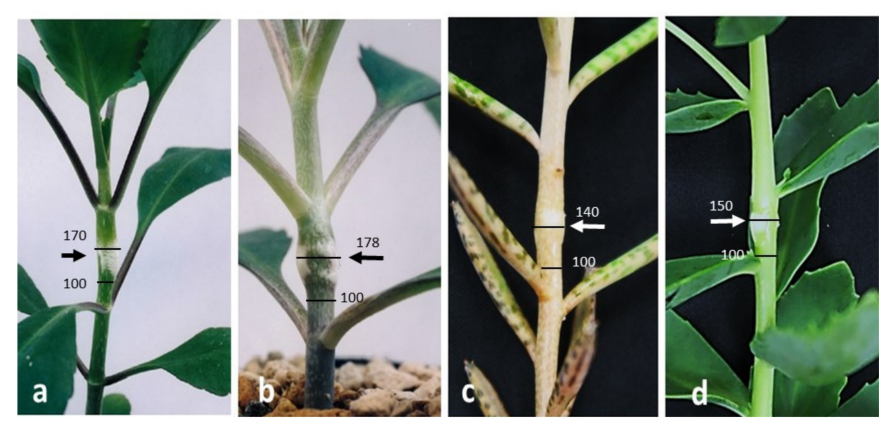

Figure 1. Conspicuous local stem swelling in succulent plants induced by NPA $(0.4 \%$, $w / w$ in lanolin) after 8 days of treatment. (a) Bryophyllum calycinum, (b) B. daigremontianum, (c) Kalanchoe tubiflora, and (d) Sedum spectabile. Arrows indicate the site of NPA application as a 2-mm-wide ring of lanolin paste around the stem in the intensively growing internode. Values with lines in the photographs indicate relative stem diameter (\%) to the non-treated area (100\%) based on the photographs.

\subsection{Histological Analyses of Conspicuous Local Stem Swelling in Succulent Plants}

Figure 2 shows anatomical observations of $B$. calycinum stem eight days after treatment with or without NPA $(0.4 \%, w / w$ in lanolin).

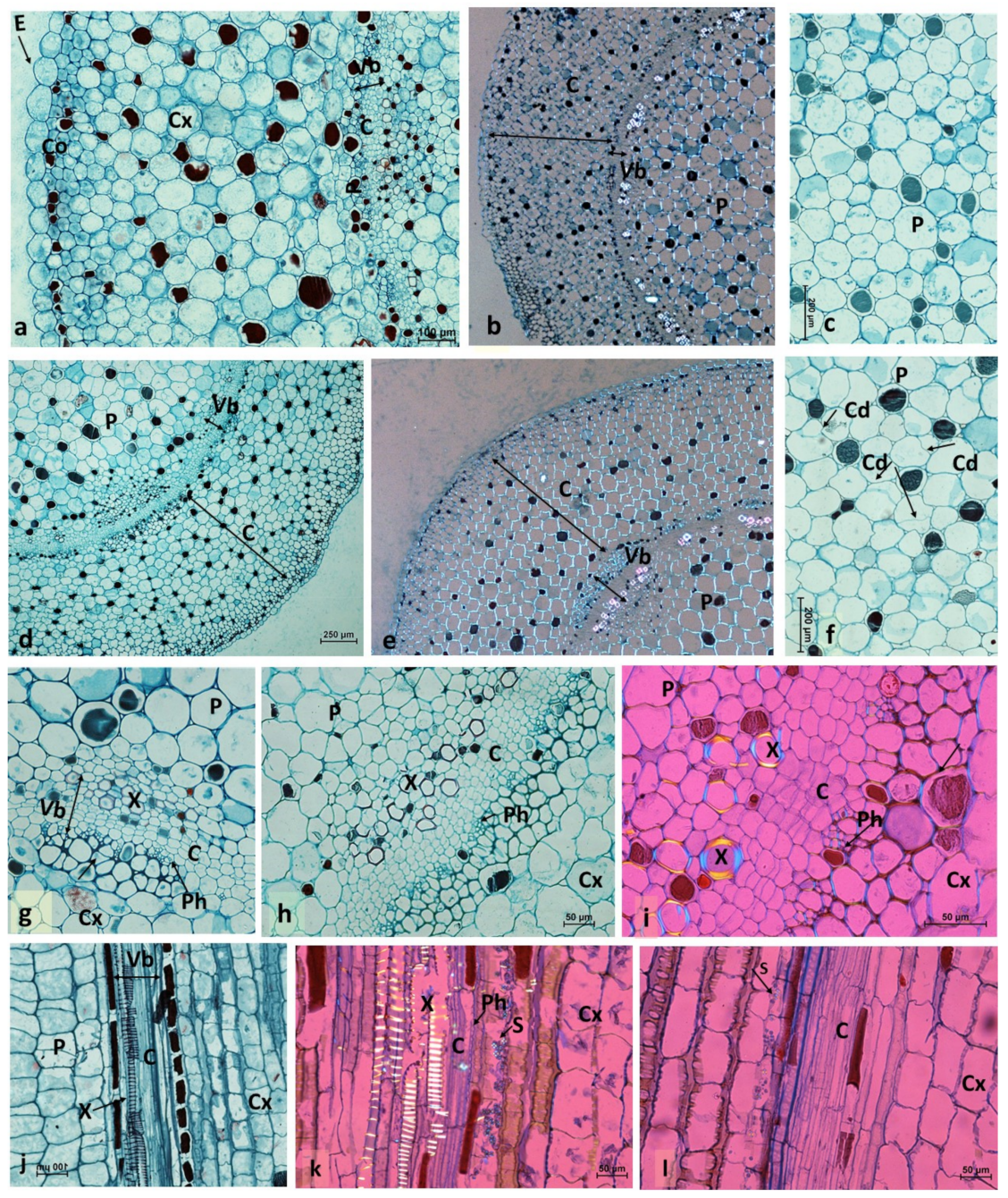

Figure 2. Anatomical details in the middle of B. calycinum internode. (a-c): Cross-section of the Scheme 0 . $w / w)$. (d): Cross-section under LM. (e): Cross-section under LMP. (f): Fragment of the pith in LM. (g-i): Details of vascular tissue on the cross-section of the control stem under LM (g) and LMP (h), and of stem swelling induced by NPA application under LMP (i). (j-1): Details of vascular tissue on the longitudinal section of the control stem under LM ( $\mathbf{j}$ ) and LMP (k), and of conspicuous local stem swelling induced by NPA under LMP (1). C: cambium; Cd: cell division; Co: collenchyma; Cx: cortex; E: epidermis; P: pith; Ph: phloem; S: starch; VB; vascular tissues; X: xylem. 
The stem surface of the control plants was covered by large epidermal cells (E) and several layers of collenchyma cells (Cx) (Figure 2a). Both cortex and pith consisted of large, vacuolated collenchymatous cells, whose cell walls glowed in the polarized light microscopy image (LMP) (Figure 2a-c). In B. calycinum, vascular tissue was found at the border between cortex and pith. Cambium formed a ring consisting of 2-3 cell layers surrounded by a cluster of phloem elements from the side of cortex and a cluster of xylem elements from the side of pith (Figure 2b,g).

The effect of NPA on conspicuous local stem swelling is shown in Figure $2 \mathrm{~d}-\mathrm{f}, \mathrm{h}, \mathrm{i}, \mathrm{l}$. An extreme increase in cortex cell size was observed (Figure 2e) compared to control; moreover, numerous cell divisions were observed in pith (Figure 2f). At the site of NPA treatment, vascular tissue had a significantly wider cambial zone consisting of 5-6 cell layers, whereas phloem and xylem seemed not to be affected by NPA treatment (Figure 2h,i,l). All these processes led to an increase in stem size, resulting in conspicuous local stem swelling.

Microscopic observations were also carried out on K. tubiflora (Figure S2) and S. spectabile (Figure S3) to analyze the processes of local stem swelling formation induced by NPA $(0.4 \%, w / w$ in lanolin).

As shown in Figure S2 in K. tubiflora, in comparison to control, numerous cell divisions were observed in the cortex of NPA-treated stem, and their cell walls were formed in different directions or in both periclinal and anticlinal directions, resulting in an increase in the number of cortex cells. Moreover, significant differences between control and NPAtreated plants were observed in vascular tissues. In control plants, cambium consisted of 3-4 cell layers, and xylem elements glowed in polarized light, while vascular tissue in NPA-treated plants had a significantly wider cambial zone consisting of approximately 6-7 cell layers, and no glowing ring of xylem cells was observed in the conspicuous local swelling area under polarized light. Anticlinal cell divisions were observed in cambium of NPA-treated plants.

Numerous cell divisions and an increase in the size of cortex cells were observed in S. spectabile stem treated with NPA compared to control (Figure S3). A significant increase in the size of parynchymatous cells was also observed in the pith. At the site of NPA treatment, vascular tissues had significantly wider cambial and xylem zones compared to control. A higher number of cambium layers was also observed in the longitudinal section. All these processes in S. spectabile led to conspicuous local stem swelling.

All the above processes led to an increase in stem size in K. tubiflora, S. spectabile, and B. calycinum, resulting in conspicuous local stem swelling.

2.3. Endogenous Levels of Plant Hormones in Relation to NPA-Induced Conspicuous Local Stem Swelling in Succulent Plants

Eight days after treatment with or without NPA $(0.4 \%, w / w$ in lanolin), endogenous levels of plant hormones in B. calycinum and B. daigremontianum were investigated in 4-5-mm internode segments at the treatment site, and in the areas above and below the treatment (Figure 3 and Figure S4, and Table 1 and Table S2).

IAA was successfully identified in the control stem treated only with lanolin for 8 days. The application of lanolin alone had no effect on IAA level at the site, and the areas above and below the treatment in B. calycinum. On the other hand, NPA treatment significantly increased endogenous IAA levels only in the area of stem swelling, but not in the areas above and below the treatment (Figure 3a). 

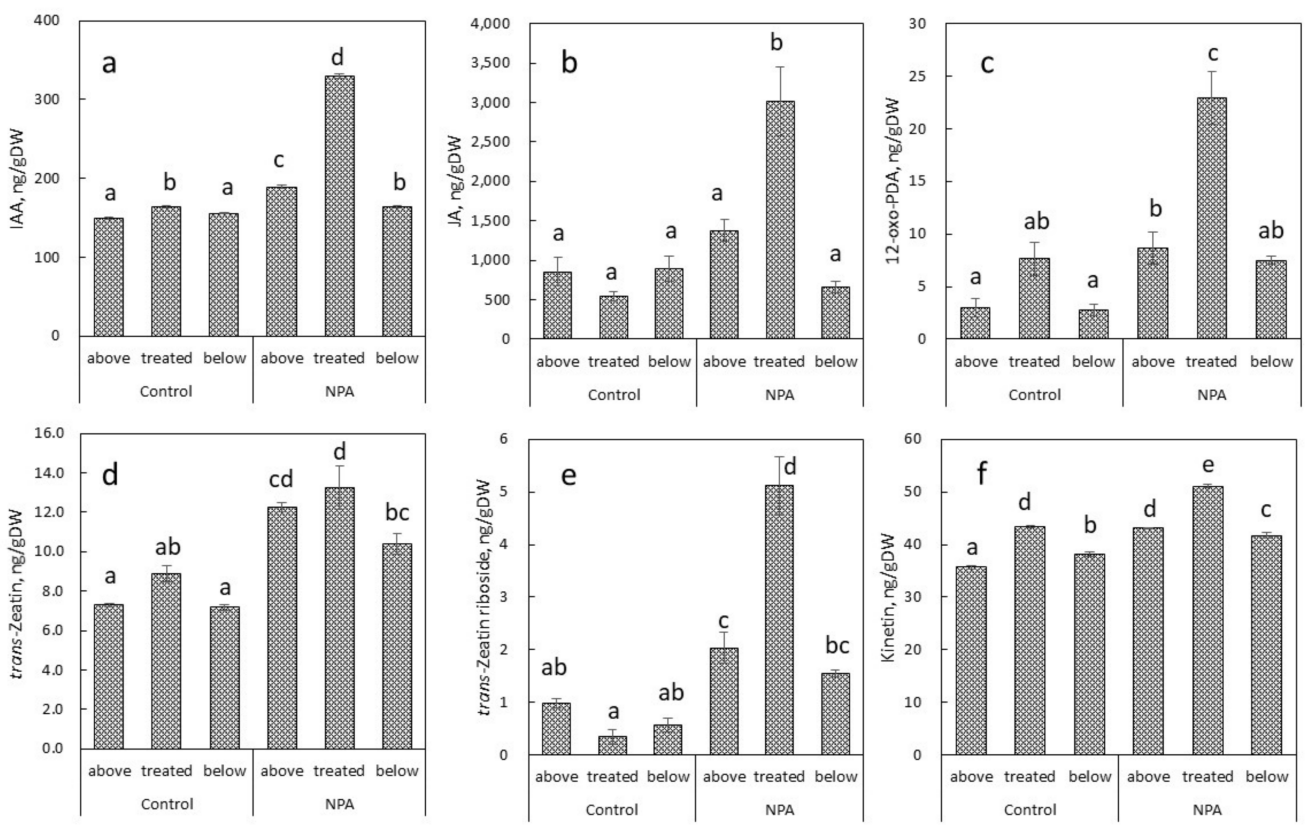

Figure 3. Effect of NPA $(0.4 \%, w / w$ in lanolin) on endogenous levels of IAA (a), jasmonic acid (JA) (b), 12-oxo-phytodienoic acid (12-oxo-PDA) (c), trans-zeatin (d), trans-zeatin riboside (e), and kinetin (f) in 4-5-mm pieces of internode at the NPA treatment site, and areas above and below in B. calycinum. Treated, above and below in the figure indicate plant hormone levels at, above and below areas of the treatment, respectively. Values are means with standard errors $(n=3)$. Different letters indicate statistical differences in Duncan's multiple range test at $p<0.05$ after analysis of variance (ANOVA).

Table 1. Effect of NPA $(0.4 \%, w / w)$ on endogenous levels of abscisic acid, salicylic acid, cis-zeatin, cis-zeatin riboside, and gibberellins determined in 4-5-mm stem pieces treated with or without NPA in B. calycinum. Above and below in the table indicate plant hormone levels in the above and the below areas of the treatment, respectively. Values are the means with standard errors $(n=3)$. Different letters indicate a statistical difference in Duncan's multiple range test at $p<0.05$ after ANOVA.

\begin{tabular}{|c|c|c|c|c|c|c|}
\hline \multirow{2}{*}{$\begin{array}{c}\text { Plant Hormone, } \\
\text { ng/gDW }\end{array}$} & \multicolumn{3}{|c|}{ Control (Lanolin) } & \multicolumn{3}{|c|}{ NPA Treatment } \\
\hline & Above & Treated Area & Below & Above & Treated Area & Below \\
\hline Abscisic acid & $163.3 \pm 2.9 b$ & $204.9 \pm 6.2 b$ & $211.0 \pm 4.8 \mathrm{~b}, \mathrm{c}$ & $209.6 \pm 3.7 \mathrm{a}$ & $260.1 \pm 17.0 \mathrm{a}$ & $239.7 \pm 5.7 c$ \\
\hline Salicylic acid & $1509 \pm 157 b, c$ & $1520 \pm 134 a, b, c$ & $2254 \pm 288 \mathrm{a}$ & $2332 \pm 70 b, c$ & $4631 \pm 787 \mathrm{c}$ & $1667 \pm 106 \mathrm{a}, \mathrm{b}$ \\
\hline cis-Zeatin & $5.5 \pm 0.17 \mathrm{a}$ & $7.1 \pm 0.16 \mathrm{c}$ & $6.2 \pm 0.07 b$ & $6.8 \pm 0.22 b, c$ & $8.7 \pm 0.27 \mathrm{~d}$ & $7.1 \pm 0.07 c$ \\
\hline cis-Zeatin riboside & $0.1 \pm 0.06 \mathrm{a}$ & $0.2 \pm 0.16 \mathrm{a}$ & $0.0 \pm 0.01 \mathrm{a}$ & $0.5 \pm 0.16 a$ & $1.2 \pm 0.0 .37 b$ & $0.5 \pm 0.12 \mathrm{a}$ \\
\hline Gibberellin $\mathrm{A}_{1}$ & $13.8 \pm 0.8 c$ & $18.1 \pm 1.4 \mathrm{~b}$ & $23.5 \pm 1.1 c$ & $14.6 \pm 1.2 \mathrm{a}$ & $20.9 \pm 0.9 a$ & $21.7 \pm 1.3 c$ \\
\hline Gibberellin $\mathrm{A}_{4}$ & $5.0 \pm 1.0 \mathrm{a}$ & $6.7 \pm 0.9 \mathrm{a}$ & $6.3 \pm 1.8 \mathrm{a}$ & $9.4 \pm 1.8 \mathrm{a}$ & $9.7 \pm 2.7 \mathrm{~b}$ & $8.4 \pm 2.7 \mathrm{a}$ \\
\hline Gibberellin $\mathrm{A}_{19}$ & $35.5 \pm 1.9 b$ & $44.7 \pm 0.7 \mathrm{a}$ & $48.9 \pm 0.8 \mathrm{a}$ & $53.5 \pm 0.3 \mathrm{~b}$ & $47.4 \pm 2.9 \mathrm{~b}$ & $52.5 \pm 2.7 b$ \\
\hline Gibberellin $\mathrm{A}_{44}$ & $3.0 \pm 0.1 \mathrm{~b}$ & $4.1 \pm 0.1 \mathrm{~b}$ & $5.1 \pm 0.2 \mathrm{a}$ & $2.5 \pm$ & $4.8 \pm 0.5 \mathrm{~b}$ & $3.8 \pm 0.4 \mathrm{~b}$ \\
\hline Gibberellin $\mathrm{A}_{15}$ & $1.4 \pm 0.1 \mathrm{~b}$ & $9.2 \pm 0.2 \mathrm{a}$ & $1.1 \pm 0.1 \mathrm{~b}$ & $1.6 \pm 0.1 \mathrm{~b}$ & $1.2 \pm 0.5 \mathrm{a}$ & $2.5 \pm 0.2 \mathrm{a}$ \\
\hline Gibberellin $A_{53}$ & $21.5 \pm 2.1 b$ & $54.2 \pm 4.7 c$ & $106.7 \pm 2.6 c$ & $55.6 \pm 2.6 \mathrm{a}$ & $63.3 \pm 14.3 \mathrm{~d}$ & $129.8 \pm 9.7 b, c$ \\
\hline Gibberellin $\mathrm{A}_{9}$ & $35.3 \pm 2.7 \mathrm{a}, \mathrm{b}$ & $43.7 \pm 0.9 \mathrm{~b}, \mathrm{c}$ & $41.0 \pm 5.7 \mathrm{a}$ & $39.4 \pm 1.6 \mathrm{~d}$ & $40.3 \pm 3.2 c$ & $49.2 \pm 1.6 \mathrm{~b}, \mathrm{c}$ \\
\hline Gibberellin $\mathrm{A}_{8}$ & $50.7 \pm 11.7 \mathrm{a}, \mathrm{b}$ & $64.9 \pm 29.6 b, c$ & $72.9 \pm 8.2 \mathrm{a}$ & $72.1 \pm 9.9 c$ & $79.2 \pm 16.8 c$ & $76.0 \pm 18.8 \mathrm{a}$ \\
\hline
\end{tabular}

Endogenous jasmonic acid (JA) and 12-oxo-phytodienoic acid (12-oxo-PDA), an important precursor of JA, were also detected in B. calycinum stem, whereas 12-oxo-PDA was present at low concentrations (Figure $3 b, c$ ). Increased endogenous levels of these compounds were especially detected at the area of NPA treatment in comparison to the areas above and below the treatment. Endogenous level of salicylic acid (SA) was also increased by NPA treatment (Table 1). Until now, there is no available data about the connection of NPA on the metabolism of SA in plants. On the other hand, it is well known that SA is an inhibitor of ethylene and JA biosynthesis.

Five cytokinins, trans-zeatin, cis-zeatin, trans-zeatin riboside, cis-zeatin riboside, and kinetin (KN), were found in B. calycinum stem. Endogenous levels of trans-zeatin, trans- 
zeatin riboside, and kinetin were substantially increased by NPA treatment, especially at the area of stem swelling (Figure $3 \mathrm{~d}-\mathrm{f}$ ). Endogenous levels of cis-zeatin and cis-zeatin riboside were almost the same in all areas tested in the control plants and NPA application slightly increased these levels (Table 1).

On the other hand, only small differences in abscisic acid (ABA) levels were found between the swelling area of the stem induced by NPA and the areas above and below the treatment (Table 1).

Gibberellins (GAs), $\mathrm{GA}_{1}, \mathrm{GA}_{4}, \mathrm{GA}_{8}, \mathrm{GA}_{9}, \mathrm{GA}_{13}, \mathrm{GA}_{19}, \mathrm{GA}_{44}$, and $\mathrm{GA}_{53}$ were detected in the stem (Table 1). $\mathrm{GA}_{8}, \mathrm{GA}_{9}, \mathrm{GA}_{19}, \mathrm{GA}_{53}$, and $\mathrm{GA}_{1}$ occurred at the highest levels and the concentrations of $\mathrm{GA}_{15}, \mathrm{GA}_{4}$, and $\mathrm{GA}_{44}$ were low. NPA treatment had little effect on the levels of these GAs.

Increased levels of IAA, JA and 12-oxo-PDA, SA, trans-zeatin riboside, and cis-zeatin riboside were observed in $B$. daigremontianum treated with NPA, and they were similar to those in B. calycinum (Figure S4 and Table S2).

The results described above indicate that the application of NPA to plant species of the genus Bryophyllum induces changes in endogenous levels of several plant hormones.

\subsection{Effect of NPA on Polar Auxin Transport in Bryophyllum Calycinum Stem Segments}

The effect of NPA on polar auxin transport in B. calycinum internode was investigated using radiolabeled ${ }^{14} \mathrm{C}$-indole-3-acetic acid $\left(\left[1-{ }^{14} \mathrm{C}\right] \mathrm{IAA}\right)$ and compared to that of TIBA. Figure $4 \mathrm{~A}$ shows that NPA applied at the middle of the internode segment as a lanolin paste did not inhibit polar auxin transport, whereas TIBA significantly inhibited it. NPA pretreatment of intact plants for $24 \mathrm{~h}$ prior to the polar auxin transport experiment showed no effect on polar auxin transport, but TIBA significantly inhibited it (Figure 4B).
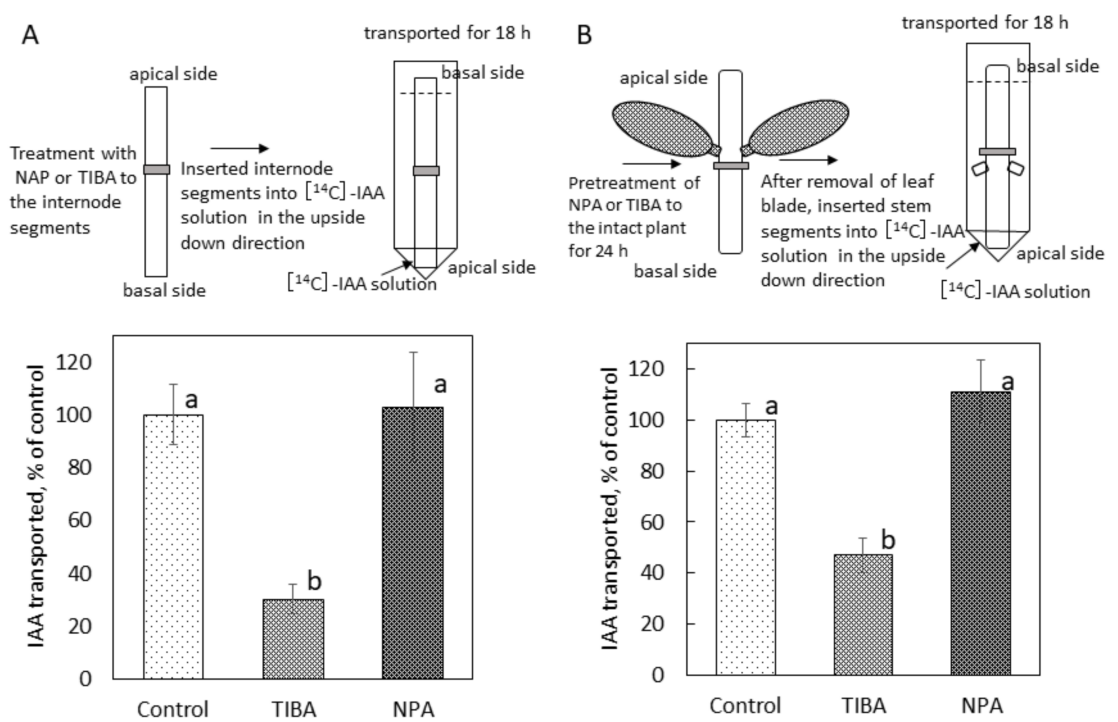

Figure 4. Effect of NPA and TIBA on polar auxin transport in stem segments of B. calycinum. (A): Internode segments ( $25 \mathrm{~mm}$ in length) were prepared, and then, lanolin with or without NPA $(0.4 \%, w / w$ in lanolin) or TIBA $(0.4 \%, w / w$ in lanolin) was applied to the middle of the internode. (B): Internode segments ( $40 \mathrm{~mm}$ in length) were prepared from intact stems pretreated with TIBA or NPA for $24 \mathrm{~h}$ prior to the experiment. Internode segments treated only with lanolin served as control segments. After removing leaf blade, the stem segments were placed into vials facing down the apical side. Polar auxin transport was assessed by radioactivity of $\left[{ }^{14} \mathrm{C}\right]-\mathrm{IAA}$ transported from the apical to the basal end of the stem segments for $18 \mathrm{~h}$. The results were expressed as percentages of control values. Vertical lines represent SE of the mean $(n=3)$. Different letters indicate statistical difference in Student's $t$-test at $p<0.05$ after ANOVA. 


\section{Discussion}

As described in the Introduction, inhibitors of polar auxin transport such as NPA, TIBA, and morphactins (IT 3456, HFCA) were expected to perturb plant growth and development (see review by Ueda et al. [6]). NPA induced conspicuous local stem swelling in succulent plants. Unlike NPA, TIBA and morphactin (IT 3456, HFCA) application to the internode of intact Bryophyllum calycinum plants did not induce such conspicuous local swelling, while they induced slight swelling along the entire stem above the treated area ([11]; Saniewski et al., unpublished results). It is important to elucidate the mode of novel physiological action of NPA in conspicuous local stem swelling for stiffening of plants, food production, and its industry [12,13].

As shown in Figure 1, our previous results [11] that NPA application as a lanolin paste induced conspicuous local stem swelling of B. calycinum were confirmed in the current study. Such NPA-induced conspicuous local stem swellings were commonly observed in other genera of succulent plants, e.g., Kalanchoe and Sedum. This observation was true for the rooting of shoot cuttings of succulent plants (Figure S1 and Table S1). The application of NPA to B. calycinum shoot cuttings did not suppress adventitious root formation of shoot cuttings, as previously reported by Saniewski et al. [7]. This lack of NPA effect on rooting was observed in shoot cuttings of B. daigremontianum, K. tubiflora and K. blossfeldiana, and S. spectabile, while TIBA, morphactin 3456, and HFCA completely inhibited it in these species. These results strongly suggest that, unlike TIBA and HFCA, NPA does not inhibit polar auxin transport in succulent plants.

The application of NPA to the middle area of the stem did not affect polar auxin transport in B. calycinum, but TIBA significantly inhibited it, even when the stem was pretreated for $24 \mathrm{~h}$ with NPA prior to the bioassay-driven polar auxin transport experiment (Figure 4). The reason of this apparent discrepancy in the mode of action of NPA and other inhibitors of polar auxin transport (TIBA and morphactins) on rooting, conspicuous local stem swelling and polar auxin transport in succulent plants has not yet been elucidated; however, different interaction with other proteins relevant to polar auxin transport is possible and cannot be excluded [6,7]. Based on the study involving transcript, protein, and metabolite temporal dynamics in the Crassulacean acid metabolism (CAM) plant Agave [14], along with the fact that CAM plants are different from $\mathrm{C} 3$ plants in photosynthetic mechanisms, it cannot be excluded that NPA binding and/or associated proteins in B. calycinum are not the same as in C3 plants such as Arabidopsis. As opposed to TIBA, NPA hardly inhibited hypocotyl rhizogenesis of the CAM plant Mesembryanthemum crystallinum [15]. TIBA increased root bud growth in the CAM plant Euphorbia escula [16], but NPA had little effect on root bud growth [17]. NPA did not affect the formation of vegetative structures at bracteoles, which are formed after flower bud removal in Agave tequilana [18]. Considering these facts, different effects of NPA from other polar auxin transport inhibitors are believed to be due to the ineffectiveness or lesser effect of NPA on polar auxin transport in the stem of succulent plants. Different subsets of auxin transport molecules may be involved in the unusual effect of NPA compared to TIBA.

Histological analyses of conspicuous local stem swelling induced by NPA revealed that a marked increase in cortex cell size, numerous cell divisions of pith cells, and a significantly wider cambial zone consisting of 5-6 cell layers were observed as compared to the untreated stem (Figure 2). Stimulation of cambium activity by NPA was commonly observed in other species, e.g., K. tubiflora (Figure S2) and S. spectabile (Figure S3), as well as the induction of local stem swelling. Moreover, numerous cell divisions were observed in the cortex and pith, accompanied either by an increase in cell size or a change in the shape. The reaction to NPA treatment of other elements of vascular tissues varied depending on the species, and the phloem and xylem in B. calycinum seemed not to be affected. In $S$. spectabile, enlargement of the xylem zone was observed, while the loss of lignification by some xylem elements was manifested in K. tubiflora as a lack of cell illuminance under LMP. These results suggested that the common feature, i.e., stimulation of cambium activity and enlargement of this zone, multiple cell divisions of cortex and pith, accompanied by 
an increase in cell size or change of shape in NPA treatment, led to an increase in stem size, resulting in conspicuous local stem swelling.

Auxin is a factor that triggers cell divisions in plant cultures, including the tobacco (Nicotiana tabacum cv. Virginia Bright Italia) VBI-0 cell line [19]. Campanoni et al. [19] showed that NPA at a concentration of $5 \mu \mathrm{M}$, at which auxin transport is impaired but not completely eliminated, did not reduce the overall rate of cell divisions and viability; however, the distribution of cell divisions was strongly altered without affecting cell elongation. NPA at a concentration of $50 \mu \mathrm{M}$, which completely blocks polar auxin transport in tobacco, greatly inhibited cell divisions and stimulated cell elongation, and caused a dramatic loss of file polarity [19]. In light-grown tomato seedlings, NPA inhibited root growth, but contrary to Arabidopsis, it stimulated hypocotyl elongation and epidermal cells of NPA-treated seedlings were more elongated and narrower than control seedlings [20]. These results suggested that in addition to cambial activity, cell division stimulation in cortex and pith tissues by NPA was induced in succulent plants by a local auxin accumulation caused by NPA application.

Relatively little information is available about the effect of NPA on cellular metabolism and endogenous auxins. As shown in Figure $3 \mathrm{a}$ and Figure S4a, NPA application to stems of $B$. calycinum and B. daigremontianum induced significantly increased levels of endogenous IAA at the site of its application, while this effect was not observed in the areas above and below the treatment. Ringing inflorescence stems with NPA of intact Arabidopsis thaliana inhibited stem radial development below the ringing site, as well as the development of fascicular xylem, interfascicular xylem and interfascicular extraxylary fibers; however, fascicular xylem production was enhanced in the area above the ringing [21]. Suer et al. [22] documented that NPA-induced auxin accumulation stimulated cambium activity in the stems of wild-type Arabidopsis thaliana, but not in WOX4 mutants, although basal cambial activity was not abolished. Ji et al. [23] and Hirakawa et al. [24] identified an important role of WOX4 transcription factor in promoting cambial activity. Thus, Suer et al. [22] have shown that WOX4 is one of essential factors that make the cambium responsive to the longdistance regulation by auxin transported basipetally along the stem. Mattsson et al. [25] showed that plants (Arabidopsis thaliana, Aurinia saxatile, Anthurium majus, Nicotiana tabacum) grown on NPA-supplemented media formed inflorescence stems with increased width of fascicular xylem and interfascicular extraxylary fibers. These results suggest that local accumulation of IAA at the NPA application site in succulent plants stimulates conspicuous local stem swelling by influencing cambial activity and cell structures in vascular tissues. The mechanism of local accumulation of IAA at the site of NPA application has not been elucidated, but almost lack of inhibition of polar auxin transport, compared to TIBA and HFCA, or de novo synthesis of IAA in the treated area might be possibly involved.

While relatively little information is available about the effect of NPA on other plant hormones in relation to conspicuous local stem swelling, comprehensive analyses of plant hormones revealed that local accumulation of IAA and cytokinins was found in the NPA-treated area of B. calycinum and B. daigremontianum stems (Figure 3 and Figure S4, and Table 1 and Table S2). Cytokinins are known to be essential in promoting mitotic cell division and regulating cell cycle in the shoot, and they play a key role in organizing new shoot apical meristems [26,27]. Cytokinins stimulated stem diameter enlargement by promoting cell division in potato plants [28]. Shibaoka [29] documented that kinetin-induced stem thickening of light-grown epicotyl segments of Azuki bean was caused by changes in the orientation of cell wall microtubules from randomly oriented to parallel to the cell axis. Cytokinins have been demonstrated to induce a greater thickness of intact etiolated pea seedlings [30], and this effect was more pronounced the presence of auxin in stem segments of etiolated and light-grown pea seedlings, soybean seedlings, and others [31-34]. After removing all leaves and flower buds in tulip plants, the application of IAA at a concentration of 0.1 and $2.0 \%(w / w$ in lanolin) to the decapitated site greatly restored stem growth, while the additional application of benzyladenine (BA) to the tulip stem by soaking a cotton wick wrapped around all internodes, significantly stim- 
ulated thickening of all internodes [35]. NPA application mimicked cytokinin induction of the off-the-medium growth of Arabidopsis root tip [36], as well as the effect of exogenous cytokinin in inducing root-like organogenesis in excised Arabidopsis hypocotyls [37]. Hu et al. [38] indicated that NPA also enhanced shoot organogenesis in citrus epicotyl explants, independent of its involvement in auxin transport, and demonstrated that the promotional effect of NPA on shoot organogenesis was cytokinin-dependent. Interestingly, BA at a concentration of $0.2 \%$ also induced local stem swelling in intact B. calycinum to a degree similar to NPA treatment (Figure S5); however, BA did not induce swelling in decapitated internode of B. calycinum. In stem mustard (Brassica juncea var. tsatsai cultivar), the contents of zeatins, including zeatin ribosides and IAA have been demonstrated to correlate with stem swelling induced by ambient (or relatively low) temperature [13]. These facts suggest that cytokinin effect on conspicuous local stem swelling is closely related to local auxin accumulation in B. calycinum. Local NPA action mechanism in the stem might be based on a response involving crosstalk between the auxin and cytokinin regulatory pathways.

The application of NPA also induced changes in endogenous levels of JA and its precursor, 12-oxo-PDA, in the swollen part of the stem induced by NPA (Figure 3 and Figure S4, Table 1 and Table S2). Jasmonates (JAs), referred to as jasmonic acid and its related compounds, have been demonstrated to exhibit tuber-inducing activity in potato stolons [39]. In isolated tomato roots cultured in vitro, JA induced swollen root apices and increased cellular vacuolation, and JA did not act directly through ethylene [40]. A close functional relationship between the JA signaling pathway and auxin homeostasis has been also documented [41-44]. These results suggest that the NPA-induced increase in endogenous levels of JAs and its interaction with IAA contribute to the regulation of conspicuous local stem swellings in Bryophyllum plants.

Further research explaining the mechanism of NPA-induced local accumulation of IAA and cytokinins as well as JAs will be required in the near future.

\section{Materials and Methods}

\subsection{Plant Materials and the Application of NPA and TIBA}

Bryophyllum calycinum plants (4-6-month-old) propagated from the buds formed in the marginal notches of excised leaves and grown under natural light conditions and temperature in a glasshouse were used for the experiments.

The plants were treated with 1-naphthylphthalamic acid [(NPA, 0.4\%, w/w)] (SigmaAldrich Ltd., St. Louis, MO, USA) or 2,3,5-triiodobenzoic acid [(TIBA, 0.4\%, w/w)] (SigmaAldrich Ltd., St. Louis, MO, USA) in a lanolin paste as a 2-mm-wide ring around the stem in the internode with intensive growth. Plants treated with lanolin only were used as control. For histological analyses, the experiments were repeated at least four times with 10 to 15 plants, and the experiments involving comprehensive analyses of endogenous plants hormones, were carried out using 25 plants for NPA treatment and lanolin treatment only (control), respectively.

In some experiments, 4- to 6-month-old B. daigremontianum and Kalanchoe tubiflora plants propagated from naturally formed plantlets on leaves and grown under natural light conditions and temperature in a glasshouse were used. Sedum spectabile, an ornamental herbaceous perennial plant of the family Crassulaceae, growing outside under natural conditions in a garden or in a glasshouse at The National Institute of Horticultural Research, Skierniewice, Poland in the period from early July to September was also used.

\subsection{Histological Analyses of Conspicuous Local Stem Swelling in Succulent Plants}

Histological analyses of conspicuous local stem swelling induced by $0.4 \%$ NPA in B. calycinum at the site of NPA application and the areas above and below were made 8 days after treatment. For histological observation, $0.7-\mathrm{cm}$ stem pieces were excised from the swollen areas induced by NPA, and regions above and below the NPA treatment in the 
same plants; corresponding fragments from untreated plants were used as controls. Five samples of internode segments were collected from each shoot.

The materials were fixed in a solution of chromic acid, acetic acid, and formalin (CrAF) for $48 \mathrm{~h}$ at room temperature, dehydrated through an increasing alcohol series (70\%, 80\%, 90\% and 100\%), and embedded in paraffin according to the method reported previously [45]. Transverse and longitudinal sections (12- $\mu \mathrm{m}$-thick) were cut with a rotary microtome (Leica, Wetzelar, Germany) and stained with safranin (1\% prepared in ultrapure water) and fast green (1\% prepared in 95\% ethanol). The sections were mounted in Canada balsam and analyzed using a light microscope (Eclipse 80i, Nikon, Tokyo, Japan) with NIS-Elements BR ver. 4.00 imaging software (Nikon Instruments Inc., Tokyo, Japan) for photo documentation.

Similar histological analyses of conspicuous local stem swelling induced by $0.4 \%$ NPA were also carried out in the stems of K. tubiflora and S. spectabile.

\subsection{Comprehensive Analyses of Endogenous Plant Hormones in Succulent Plants}

Eight days after treatment with NPA and lanolin only of B. calycinum plants, 4- to 5 -mm internode fragments were excised in the swollen area and the areas above and below it with or without NPA treatment. The samples were frozen, lyophilized, and powdered.

Analyses of plant hormones were performed according to the methods reported previously [46-49]. The samples were spiked with a stable isotope-labeled internal standard mixture and extracted in methanol/water/formic acid solution $(15 / 4 / 1, v / v / v)$. The obtained extract was evaporated and re-suspended $1 \mathrm{M}$ formic acid with $3 \%$ of methanol. Samples underwent SPE (BondElut Plexa PCX, Agilent, Santa Clara, CA, USA) clean up as described previously $[45,46]$. Plant hormones analyses were done in triplicate on a UHPLCMS/MS system (Agilent Infinity 1260, coupled to a 6410 Triple Quad LC/MS, Agilent, Santa Clara, CA, USA). Analyses were done in positive electrospray ionization (ESI) in multiple reaction monitoring (MRM) mode. As internal standards, $\left[{ }^{15} \mathrm{~N}_{4}\right]$ dihydrozeatin, $\left[{ }^{2} \mathrm{H}_{5}\right]$ trans-zeatin riboside, $\left[{ }^{2} \mathrm{H}_{5}\right]$ indole-3-acetic acid, $\left[{ }^{2} \mathrm{H}_{4}\right]$ salicylic acid, $\left[{ }^{2} \mathrm{H}_{2}\right]$ gibberellin $\mathrm{A}_{1},\left[{ }^{2} \mathrm{H}_{2}\right]$ gibberellin $\mathrm{A}_{4},\left[{ }^{2} \mathrm{H}_{2}\right]$ gibberellin $\mathrm{A}_{5},\left[{ }^{2} \mathrm{H}_{2}\right]$ gibberellin $\mathrm{A}_{6},\left[{ }^{2} \mathrm{H}_{6}\right]$ cis, trans-abscisic acid, $\left[{ }^{2} \mathrm{H}_{5}\right]$ benzoic acid (OlChemim, Olomunc, Czech Republic), $\left[{ }^{2} \mathrm{H}_{5}\right]$ jasmonic acid (CND Isotopes, QC, Canada), and $\left[{ }^{2} \mathrm{H} 5\right]$ dinor-12-oxo-phytodienoic acid (Cayman Chem. Comp., Ann Arbor, MI, USA) were used. The technical details are given in the cited references.

Similar analyses of plant hormones in relation to conspicuous local stem swelling induced by $0.4 \%$ NPA were carried out in B. daigremontianum stems.

\subsection{Determination of Polar Auxin Transport in Bryophyllum Calycinum Stem Segments}

Following the method reported previously $[9,10]$, with minor modifications, a system for the detection of bioassay-derived polar auxin transport was introduced consisting of $50 \mu \mathrm{L}$ and $150 \mu \mathrm{L}$ of 100 -fold diluted [ $\left.{ }^{14} \mathrm{C}\right]-\mathrm{IAA}$ with a specific activity of $55 \mathrm{mCi} / \mathrm{mmol}$, $0.1 \mathrm{mCi} / \mathrm{mL}$, (American Radiolabeled Chemicals Inc., St. Louis, MO, USA) at the bottom of 2-mL Eppendorf tubes (for $25 \mathrm{~mm}$ stem segments) and 6-mL plastic vials (for 40-mm stem segments), respectively.

Internode segments ( $25 \mathrm{~mm}$ in length) excised from growing internodes were used, mainly from the second or third internode from the top of growing plants with active elongation. NPA and TIBA $(0.4 \% w / w)$ were applied in lanolin as a 2-mm strip to the middle part around the internode segments. Internode segments treated only with lanolin served as the control segments. In another experiment, internode segments $(40 \mathrm{~mm}$ in length) prepared from the growing internode of intact plants pretreated with NPA or TIBA for $24 \mathrm{~h}$ were used to determine polar auxin transport.

The 20- and 40-mm-long segments were placed into plastic Eppendorf tubes and vials, respectively, facing down the apical side. There was almost no auxin transport observed when IAA was applied at the basal side of the segments in the same manner (data not shown). Therefore, ${ }^{14} \mathrm{C}$-labelled IAA applied to the apical side was transported to the physiological apical-basal direction in this assay system. 
After incubation at $23.5^{\circ} \mathrm{C}$ for $18 \mathrm{~h}$, a 3-mm piece was cut on the opposite side of the segment. The piece was directly put into a vial containing liquid scintillation cocktails (Universol $^{\mathrm{TM}}$-ES, MP-Biomedicals, CA, USA), and then, its radioactivity was determined using a liquid scintillation counter (Tri-Carb2200CA, Packard Instrument Co., Ltd., Meriden, CT, USA). The experiments were performed in triplicate with 6 segments. The results are expressed as percentages of the mean control values with standard errors $(n=3)$.

\subsection{Statistical Analysis}

The analysis of variance (ANOVA) was conducted using STATISTICA software (StatSoft, Kraków, Poland). When ANOVA indicated significant effects, the means were separated using Duncan's multiple range test or Student's $t$-test at $p<0.05$ considered to be statistically significant.

\section{Conclusions}

Unlike TIBA and HFCA, NPA shows unusual physiological effects that differed from other polar auxin transport inhibitors in succulent plants; NPA induced conspicuous local stem swelling in intact plants of B. calycinum and some other succulent plants as well as rooting of shoot cuttings. NPA showed almost no inhibition of polar auxin transport in B. calycinum plants. NPA also induced a significant increase in the levels of IAA, cytokinins, and JA and its precursor, 12-oxo-PDA, at its application site in succulent plants. The crosstalk of these plant hormones might regulate cell division and enlargement, resulting in conspicuous local stem swelling. Further studies on the mechanism of NPA induced local accumulation of these plant hormones will be required in the near future.

Supplementary Materials: Supplementary Materials can be found at https:/ / www.mdpi.com/1422 $-0067 / 22 / 6 / 3118 / s 1$.

Author Contributions: A.M.-C., M.S., K.M., and J.U. designed the experiments and wrote manuscript; A.M.-C., U.K., M.D., K.M. and J.U. performed the histological experiment, plant hormone analysis experiment, and polar auxin transport experiment, respectively. U.K. and J.G.-K. conducted the growth experiments. J.G.-K. carried out the software analysis. All authors have read and agreed to publish the present version of the manuscript.

Funding: This work was partly supported by the Polish Ministry of Science and Higher Education from the statutory funds of The National Institute of Horticultural Research, Skierniewice, Poland (Grant ZBS/7/2021).

Institutional Review Board Statement: Not applicable.

Informed Consent Statement: Not applicable.

Data Availability Statement: Not applicable.

Conflicts of Interest: The authors declare no conflict of interest.

\section{References}

1. Berleth, T.; Sachs, T. Plant morphogenesis: Long-distance coordination and local patterning. Curr. Opin. Plant Biol. 2001, 4, 57-62. [CrossRef]

2. Taize, L.; Zeiger, M. Plant Physiology, 3rd ed.; Sinauer Associates Inc.: Sunderland, MA, USA, 2002.

3. Petrášek, J.; Friml, J. Auxin transport routes in plant development. Development 2009, 136, 2675-2688. [CrossRef]

4. Křeček, P.; Skůpa, P.; Libus, J.; Naramoto, S.; Tejos, R.; Friml, J.; Zažímalová, E. The PIN-FORMED (PIN) protein family of auxin transporters. Genome Biol. 2009, 10, 249. [CrossRef] [PubMed]

5. Ahkami, A.H.; Melzer, M.; Ghaffari, M.R.; Pollmann, S.; Javid, M.G.; Shahinnia, F.; Hajirezaei, M.R.; Druege, U. Distribution of indole-3-acetic acid in Petunia hybrida shoot tip cuttings and relationship between auxin transport, carbohydrate metabolism and adventitious root formation. Planta 2013, 238, 499-517. [CrossRef]

6. Ueda, J.; Saniewski, M.; Miyamoto, K. Auxin, One Major Plant Hormone, in Soil. In Bioactive Compounds in Agricultural Soils; Springer International Publishing: Cham, Switzerland, 2016; pp. 175-209.

7. Saniewski, M.; Góraj, J.; Weegrzynowicz-Lesiak, E.; Miyamoto, K.; Ueda, J. Differential effects of auxin polar transport inhibitors on rooting in some Crassulaceae species. Acta Agrobot. 2014, 67, 85-92. [CrossRef] 
8. Kulka, R.G. Hormonal control of root development on epiphyllous plantlets of Bryophyllum (Kalanchoe) marnierianum: Role of auxin and ethylene. J. Exp. Bot. 2008, 59, 2361-2370. [CrossRef]

9. Ueda, J.; Góraj-Koniarska, J.; Miyamoto, K.; Saniewski, M. Epinasty and/or hyponasty, and petiole growth in Bryophyllum calycinum: Focus on the interaction of indole-3-acetic acid and methyl jasmonate. Acta Biol. Crac. Ser. Bot. $2018,60,73-81$.

10. Ueda, J.; Miyamoto, K.; Góraj-Koniarska, J.; Saniewski, M. Petiole bending in detached leaves of Bryophyllum calycinum: Rel-evance to polar auxin transport in petioles. Acta Biol. Crac. Ser. Bot. 2018, 60, 25-33.

11. Saniewski, M.; Góraj-Koniarska, J.; Gabryszewska, E.; Miyamoto, K.; Ueda, J. Differential effects of N-1-naphthylphthalamic acid (NPA) and 2,3,5-triiodobenzoic acid (TIBA) on auxin control of swelling of the shoots of Bryophyllum calycinum Salisb. Acta Agrobot. 2017, 70, 1723. [CrossRef]

12. Hoson, T.; Soga, K. New Aspects of Gravity Responses in Plant Cells. Adv. Appl. Microbiol. 2003, 229, 209-244. [CrossRef]

13. Guo, D.P.; Jiang, Y.T.; Zeng, G.W.; Ali, G. Stem swelling of stem mustard, as affected by temperature and growth regulators. Sci.Hortic. 1994, 60, 153-160. [CrossRef]

14. Abraham, P.E.; Yin, H.; Borland, A.M.; Weighill, D.; Lim, S.D.; De Paoli, H.C.; Engle, N.; Jones, P.C.; Agh, R.; Weston, D.J.; et al Transcript, protein and metabolite temporal dynamics in the CAM plant Agave. Nat. Plants 2016, 2, 16178. [CrossRef] [PubMed]

15. Konieczny, R.; Kępczyński, J.; Pilarska, M.; Cembrowska, D.; Menzel, D.; Samaj, J. Cytokinin and ethylene affect auxin transportdependent rhizogenesis in hypocotyls of common ice plant (Mesembryanthemum crystallinum L.). J. Plant. Growth Regul. 2009, 28, 331-340. [CrossRef]

16. Nissen, S.J.; Foley, M.E. Correlative inhibition and dormancy in root buds of leafy spurge (Euphorbia escula). Weed Sci. 1987, 35, 155-159. [CrossRef]

17. Horvath, D.P. The role of specific plant organs and polar auxin transport on correlative inhibition of leafy spurge (Euphorbia escula) root buds. Can. J. Bot. 1998, 76, 1227-1235.

18. Juárez, M.J.A.; Cárdenas, R.H.; Villa, J.N.S.; O'Connor, D.; Sluis, A.; Hake, S.; Ordaz-Ortiz, J.; Terry, L.; Simpson, J. Functionally different PIN proteins control auxin flux during bulbil development in Agave Tequilana. J. Exp. Bot. 2015, 66, 3893-3905. [CrossRef]

19. Campanoni, P.; Blasius, B.; Nick, P. Auxin Transport Synchronizes the Pattern of Cell Division in a Tobacco Cell Line. Plant Physiol. 2003, 133, 1251-1260. [CrossRef] [PubMed]

20. Nonghmaithem, S.; Devulapalli, S.; Sreelakshmi, Y.; Sharma, R. Is naphthylphthalamic acid a specific phytotropin? It elevates ethylene and alteres metabolic homeostasis in tomato. Plant. Sci. 2020, 291, 110358. [CrossRef]

21. Little, C.H.A.; Macdonald, J.E.; Olsson, O. Involvement of Indole-3-Acetic Acid in Fascicular and Interfascicular Cambial Growth and Interfascicular Extraxylary Fiber Differentiation in Arabidopsis thaliana Inflorescence Stems. Int. J. Plant Sci. 2002, 163, 519-529. [CrossRef]

22. Suer, S.; Agusti, J.; Sanchez, P.; Schwarz, M.; Greb, T. WOX4 Imparts Auxin Responsiveness to Cambium Cells in Arabidopsis. Plant Cell 2011, 23, 3247-3259. [CrossRef]

23. Ji, J.; Strable, J.; Shimizu, R.; Koenig, D.; Sinha, N.; Scanlon, M.J. WOX4 Promotes Procambial Development. Plant Physiol. 2010, 152, 1346-1356. [CrossRef]

24. Hirakawa, Y.; Kondo, Y.; Fukuda, H. TDIF peptide signaling regulates vascular stem cell proliferation via the WOX4 home-box gene in Arabidopsis. Plant. Cell 2010, 22, 2618-2629. [CrossRef] [PubMed]

25. Mattsson, J.; Sung, Z.R.; Berleth, T. Responses of plant vascular systems to auxin transport inhibition. Development 1999, 126, 2979-2991.

26. Schaller, G.E.; Bishopp, A.; Kieber, J.J. The Yin-Yang of Hormones: Cytokinin and Auxin Interactions in Plant Development. Plant Cell 2015, 27, 44-63. [CrossRef]

27. Schaller, G.E.; Street, I.H.; Kieber, J.J. Cytokinin and the cell cycle. Curr. Opin. Plant Biol. 2014, 21, 7-15. [CrossRef] [PubMed]

28. Palmer, C.E.; Smith, O.E. Cytokinins and tuber induction in the potato plants. Nature 1969, 221, 279-280. [CrossRef]

29. Shibaoka, H. Involvement of wall microtubule in gibberellin promotion and kinetin inhibition of stem elongation. Plant. Cell Physiol. 1974, 15, 255-263.

30. Miyamoto, K.; Kato-Noguchi, H.; Hashimoto, T. Activities of growth inhibitors isolated from light-grown dwarf pea shoots. Plant Growth Regul. 1992, 11, 411-417. [CrossRef]

31. Hashimoto, T. Synergistic Effect of Indoleacetic Acid and Kinetin on the Primary Thickening of Pea Stem Segments. J. Plant Res. 1961, 74, 110-117. [CrossRef]

32. Katsumi, M. Physiological Effects of Kinetin Effect on the Thickening of Etiolated Pea Stem Sections. Physiol. Plant. 1962, 15, 115-121. [CrossRef]

33. Vanderhoef, L.N.; Stahl, C.; Siegel, N.; Zeigber, R. The inhibitions by cytokinin of auxin-promoted elongation in excised soy-bean hypocotyl. Physiol. Plant. 1973, 29, 22-27. [CrossRef]

34. Victor, T.S.; Vanderhoef, L.N. Mechanical Inhibition of Hypocotyl Elongation Induces Radial Enlargement. Plant Physiol. 1975, 56, 845-846. [CrossRef] [PubMed]

35. Saniewski, M.; Węgrzynowicz-Lesiak, E.; Góraj-Koniarska, J.; Gabryszewska, E. Effect of benzyladenine (BA) on aux-in-induced stem elongation and thickening in tulip (Tulipa gesneriana L.). Acta Agrobot. 2016, 69, 1650.

36. Kushwah, S.; Jones, A.M.; Laxmi, A. Cytokinin Interplay with Ethylene, Auxin, and Glucose Signaling Controls Arabidopsis Seedling Root Directional Growth. Plant Physiol. 2011, 156, 1851-1866. [CrossRef] [PubMed] 
37. Pernisová, M.; Klima, P.; Horák, J.; Valková, M.; Malbeck, J.; Souček, P.; Reichman, P.; Hoyerová, K.; Dubová, J.; Friml, J.; et al. Cytokinins modulate auxin-induced organogenesis in plants via regulation of the auxin efflux. Proc. Natl. Acad. Sci. USA 2009, 106, 3609-3614. [CrossRef]

38. Hu, W.; Fagundez, S.; Katin-Grazzini, L.; Li, Y.; Li, W.; Chen, Y.; Wang, X.; Deng, Z.; Xie, S.; McAvoy, R.J. Endogenous auxin and its manipulation influence in vitro shoot organogenesis of citrus epicotyl explants. Hortic. Res. 2017, 4, 17071. [CrossRef] [PubMed]

39. Koda, Y.; Kikuta, Y.; Tazaki, H.; Tsujino, Y.; Sakamura, S.; Yoshihara, T. Potato tuber-inducing activities of jasmonic acid and related compounds. Phytochemistry 1991, 30, 1435-1438. [CrossRef]

40. Tung, P.; Hooker, T.S.; Tampe, P.A.; Reid, D.M.; Thorpe, T.A. Jasmonic Acid: Effects on Growth and Development of Isolated Tomato Roots Cultured In vitro. Int. J. Plant Sci. 1996, 157, 713-721. [CrossRef]

41. Hentrich, M.; Böttcher, C.; Düchting, P.; Cheng, Y.; Zhao, Y.; Berkowitz, O.; Masle, J.; Medina, J.; Pollmann, S. The jasmonic acid signaling pathway is linked to auxin homeostasis through the modulation of YUCCA8andYUCCA9gene expression. Plant J. 2013, 74, 626-637. [CrossRef] [PubMed]

42. Pérez, A.C.; Goossens, A. Jasmonate signaling: A copycat of auxin signaling? Plant. Cell Environ. 2013, 36, 2071-2084. [CrossRef] [PubMed]

43. Du, H.; Liu, H.; Xiong, L. Endogenous auxin and jasmonic acid levels are differentially modulated by abiotic stresses in rice. Front. Plant Sci. 2013, 4, 397. [CrossRef] [PubMed]

44. Pazmino, D.M.; Rodriguez-Serrano, M.; Romero-Puertas, M.C.; Sandalio, L.M. Regulation of epinasty induced by 2,4dichlorophenoxyacetic acid in pea and Arabidopsis plants. Biol. Plant. 2014, 16, 809-818. [CrossRef]

45. Marasek-Ciolakowska, A.; Saniewski, M.; Dziurka, M.; Kowalska, U.; Góraj-Koniarska, J.; Ueda, J.; Miyamoto, K. Formation of the Secondary Abscission Zone Induced by the Interaction of Methyl Jasmonate and Auxin in Bryophyllum calycinum: Relevance to Auxin Status and Histology. Int. J. Mol. Sci. 2020, 21, 2784. [CrossRef] [PubMed]

46. Dziurka, M.; Janeczko, A.; Juhász, C.; Gullner, G.; Oklestková, J.; Novák, O.; Saja, D.; Skoczowski, A.; Tóbiás, I.; Barna, B. Local and systemic hormonal responses in pepper leaves during compatible and incompatible pepper-tobamovirus interactions. Plant Physiol. Biochem. 2016, 109, 355-364. [CrossRef] [PubMed]

47. Płażek, A.; Dubert, F.; Kopeć, P.; Dziurka, M.; Kalandyk, A.; Pastuszak, J.; Wolko, B. Seed Hydropriming and Smoke Water Significantly Improve Low-Temperature Germination of Lupinus Angustifolius L. Int. J. Mol. Sci. 2018, 19, 992. [CrossRef]

48. Wiszniewska, A.; Koźmińska, A.; Hanus-Fajerska, E.; Dziurka, M.; Dziurka, K. Insight into mechanisms of multiple stresses tolerance in a halophyte Aster tripolium subjected to salinity and heavy metal stress. Ecotoxicol. Environ. Saf. 2019, 180, 12-22. [CrossRef] [PubMed]

49. Saniewski, M.; Dziurka, M.; Dziurka, K.; Góraj-Koniarska, J.; Ueda, J.; Miyamoto, K. Methyl jasmonate induces leaf senescence of Ginkgo biloba L.: Relevance to endogenous levels of plant hormones. Plant Growth Regul. 2020, 91, 383-396. [CrossRef] 